\title{
The concept of a dysfunctional family and its social danger
}

\author{
Abdulaziz RASULEV ${ }^{1}$, Alisher MURODOV ${ }^{2}$ \\ Tashkent State University of Law
}

\section{ARTICLE INFO \\ Article history: \\ Received January 2021 \\ Received in revised form \\ 15 January 2021 \\ Accepted 20 January 2021 \\ Available online \\ 01 February 2021}

\footnotetext{
Keywords:

family in a socially

dangerous situation,

antisocial behavior,

offender,

victim,

crime situation.
}

\begin{abstract}
The article gives the concept of a family in a socially dangerous position and its social danger, offers and recommendations for the prevention of offenses committed in the family and domestic sphere as well as their causes and conditions, factors causing an unhealthy family climate.
\end{abstract}

2181-1415/C) 2021 in Science LLC.

This is an open access article under the Attribution 4.0 International (CC BY 4.0) license (https://creativecommons.org/licenses/by/4.0/deed.ru)

\section{SUMMARY}

In the national legislation of all countries of the world, special importance is attached to ensuring human rights and freedoms, in particular, the protection of human life, health, honor and dignity from various criminal attacks. The Universal Declaration of Human Rights recognizes that «Recognition of the inherent dignity and of the equal and inalienable rights of all members of the human family is the foundation of freedom, justice and peace in the world». In many States, numerous cases of ill-treatment and violence against women, children and the elderly have been observed in recent years within the framework of family and domestic relations. In particular, every year $38 \%$ of women, up to 1.5 billion children are exposed to various types of violence and abuse in the family, while in Europe every fifth child is subjected to sexual violence. Currently, the world pays special attention to the creation of an effective system of early warning of offenses in the field of family and domestic relations, the

\footnotetext{
${ }^{1}$ DSc., professor, Academy of the Ministry of Internal Affairs of the Republic of Uzbekistan , Tashkent, Uzbekistan. E-mail: rasuleff@mail.ru

${ }^{2} \mathrm{PhD}$ in Law, Deputy Head of the Department of Crime Prevention of the Academy of the Ministry of Internal Affairs of the Republic of Uzbekistan, Tashkent, Uzbekistan.
} 
provision of social and legal assistance to those affected by it, and the implementation of effective preventive work in this direction.

\section{Нотинч оила тушунчаси ва унинг ижтимоий хавфи}

\author{
Калит сўзлар: \\ ижтимоий жихатдан \\ хавфли ахволда бўлган \\ оила, \\ ғайриижтимоий хулқ- \\ атвор, \\ хукуқбузар, \\ жабрланувчи шахс, \\ криминоген вазият.
}

\begin{abstract}
АННОТАЦИЯ
Мақолада ижтимоий жихатдан хавфли ахволда бўлган оила тушунчаси ва унинг ижтимоий хавфи, оилада носоғлом мухитни келтириб чиқарувчи омиллар, уларнинг сабаб ва шароитлари хамда оила турмуш доирасида содир этиладиган хуқуқбузарликларнинг олдини олишга қаратилган таклиф ва тавсиялар билдирилган.
\end{abstract}

\section{Понятие неблагополучной семьи и $\mathrm{ee}$ социальная опасность}

\footnotetext{
Ключевые -слова:

семья,

находящийся в социально

опасном положение,

антисоциальное

поведение,

правонарушитель,

потерпевший,

криминогенная ситуация.
}

\begin{abstract}
АННОТАЦИЯ
В статье даны понятие семьи, находящийся в социально опасном положении и её социальная опасность, предложения и и рекомендации по предупреждение правонарушений, совершаемых в семейно-бытовой сфере, а также их причины и условий, факторы, порождающие нездорового климата в семье.
\end{abstract}

In our country, in order to increase the legal consciousness and culture of the population, improve the interaction of State bodies and civil society institutions, largescale reforms are being implemented to prevent offenses. The action strategy for the five priority areas of development of the Republic of Uzbekistan for 2017-2021 provides for such urgent tasks as «increasing the responsibility of parents in controlling the behavior of children from disadvantaged families, unorganized youth, unemployed people who have fallen under the influence of «mass culture», preventing poverty, alcohol consumption, and others». Because the moral qualities, upbringing and other characteristics of each person are formed in the family. Naturally, the influence of the social environment in the family on criminal behavior in the formation of personality is of great importance and the role of the family in its formation as an offender or in the formation of a full-fledged person.

In order to ensure the rights and freedoms of the individual in our country, reliable protection from various threats and attacks, in particular, the efficient organization of crime prevention within the family or domestic relations established the Republican scientific and practical research center «Oila», the women's Committee of Uzbekistan, the National centre for human rights of the Republic of Uzbekistan, local authorities and special institutions with them, such as «conciliation Commission», «Union of Youth of Uzbekistan». However, despite the measures taken in this direction, $28.6 \%$ of 
premeditated murders, $24.5 \%$ of intentional bodily injuries, $12.0 \%$ of insults, $6.1 \%$ of hooliganism occur precisely within the framework of family and domestic relations. When studying the reasons for the commission of these crimes and the conditions that allow them, it became known that an unhealthy socio-psychological situation in the family leads to various conflicts and quarrels in the family, as well as, as a result, to the commission of crimes that pose a danger to human life and health.

It should be noted that in order to increase the effectiveness of crime prevention in the field of family and household life, first of all, the study and scientific analysis of the causes and conditions of committing this type of crime, allowing them to continue, plays an important role in the development of systematic comprehensive preventive measures to prevent their commission. After all, «Making decisions about stability, peace and tranquility in society, unconditional respect for human rights and freedoms is an important condition for achieving the goals set for large-scale reforms aimed at further socioeconomic development of the country, improving the well-being of the population, and building a democratic state based on the rule of law» [8].

A family in a socially dangerous situation is understood as a family that evades or improperly fulfills its duties to provide, raise and educate minors by parents or persons replacing them, or has a negative impact on their behavior or leads to ill-treatment [6].

The importance of the family in the spiritual formation of the individual lies in the fact that the basis of the human personality is built in the family. A person receives in the family exactly the first knowledge and ideas about the surrounding world, the norms of morality about good and evil, an educational lesson. One of the main directions of improving the spiritual environment in the family is education in the family. As noted by the great thinker Abdullah Avloni in this respect: «Education is a matter of life, or death, or salvation, or destruction, or happiness, or disaster for us» [1].

An unhealthy social environment in the family negatively affects not only the behavior of children raised in the family, but also the behavior of family members that contradicts ethics, and the process of social relations that arise between them. According to the study, $40-45 \%$ of minors who have committed antisocial behavior live in unhealthy families, where parents were involved in drunkenness, systematic quarrels and conflicts. This suggests that people who live in an unhealthy family are almost different in behavior than others. This, in turn, gives rise to the crime situation, when the family occur in a variety of conflicts. The factors that cause family conflicts are related to each other, and the factors that cause these conflicts manifest themselves in different forms [2].

When studying the causal conditions of crimes committed within the framework of family relations, it became known that their origin is influenced by the following factors: a) unhealthy moral and psychological environment in the family; b) weakness or impotence of moral and moral education in the family; c) abnormal behavior of a member (members)family; d) material insufficiency and difficulties in the family; e) alcohol intoxication of a family member (s); f) unjustified jealousy, infidelity of a man or woman; g) undesirable interference of others in the life of young families and early marriage.

The main part of the causes and conditions analyzed above are negative relationships and an unhealthy social environment in the family. After all, the correction of negative relations in the family from a criminological point of view consists of a system of preventive measures aimed at preventing not only crimes in the family, but also all other criminal acts by influencing the family [3]. 
The formation of an unhealthy environment in the family is manifested in close connection with the following factors: a) the impact of external negative factors on the family environment; b) the lack of recognition of national traditions and values in the family, moral and pedagogical weakness; c) the tendency of family members to use alcohol, drugs or tobacco products; d) the presence of constant quarrels and conflicts between family members, etc. [5].

The analysis shows that as a result of offenses committed within the framework of family life, national traditions and values are not recognized, moral and pedagogical weakness in the family, as well as an unhealthy spiritual atmosphere in the family have a negative impact [7]. In order to avoid such unpleasant situations, first of all, it is necessary to form a healthy spiritual environment in the family in order to achieve its complete and perfect stability and strength in the family.

As the President of the Republic of Uzbekistan Sh. M. Mirziyoyev noted: «We should never forget one truth: a child left without the attention of parents, society, brings only anxiety to the family, instead of joy and benefit. Therefore, raising children and working with young people should remain the most important and urgent task for us» [4]. To do this, first of all, it is necessary to improve the moral spirit in the family, to educate minors in the spirit of national traditions and customs, to increase the responsibility of parents in this direction, to eliminate the factors that have a negative impact on the family environment. Because of the unhealthy situation in the family, quarrels, abnormal social relations between family members are the main source of the formation of moral negativity of the individual.

For the purposes of prevention of offenses in the sphere of domestic life, it is advisable to take the following preventive measures: first, to identify families in a socially dangerous situation, living in the administrative districts that provide them with social, legal and moral support, to organize educational work of persons likely to commit offenses; second, to develop measures aimed at conducting social surveys among individuals who are victims of violence within the family and domestic life, the purpose of which is hidden, and eliminating the latency of these acts; third, to ensure the effective organization of the activities of rehabilitation and adaptation centers for persons affected by violence in connection with family conflicts; fourth, to introduce the practice of preparing and regularly showing videos, videos, advertising and other works of art in the media about the causes and conditions, social risks, negative consequences of offenses in the sphere of family life, factors leading to family divorce, as well as their prevention; fifthly, the involvement in the family of persons with rich life experience, in order to timely identify persons who have committed illegal behavior within the framework of morality, contrary to national values and customs, and take appropriate measures of educational influence on them; sixth, conducting an in-depth study of the causes and conditions that contribute to the commission of offenses in the sphere of life of each family, the implementation of preventive measures aimed at their further study, analysis and prevention is important.

\section{References}

1. Avloniy A. Turkish gulistan or morality. -T., "O'qituvchi”, 1992. -B. 14.

2. Kolmakova O.S. Crimes infringing on the rights of the child in the sphere of family relations: aftoref. diss. can. jurid. sciences. -M., 2015. -S. 15. 
3. Lutfullaev Sh. Bees in the prevention and prevention of domestic crime and juvenile delinquency // Reforms in the system of crime prevention in Uzbekistan: results and prospects: Proceedings of the Republican scientific-practical conference. - T .: Academy of the Ministry of Internal Affairs of the Republic of Uzbekistan, 2015. - B. 98.

4. Mirziyoev Sh.M. We will build our great future together with our brave and noble people. -T., 2017. -B. 135.

5. Murodov A.Sh. Improving the activity of internal affairs bodies for the prevention of offenses related to domestic violence: Dissertation of the Doctor of Philosophy (Phd) in jurisprudence. -T., 2019. -S. 72.

6. Collection of legislative acts of the Republic of Uzbekistan. - T., 2010. - No. 8.2-m.

7. Tlyumbetov R.G. Crimes against the family: criminal law and criminological aspects: aftoref. diss. can. jurid. sciences. -M., 2015. -S. 12.

8. Decree of the President of the Republic of Uzbekistan dated April 10, 2017 No. UP5005 "On measures to radically increase the efficiency of the internal affairs bodies, strengthen their responsibility in ensuring public order, reliable protection of the rights, freedoms and legitimate interests of citizens." 